\title{
Optimalisasi Stakeholder Dalam Pelayanan Kesehatan Narapidana Di Lembaga Pemasyarakatan
}

\author{
Afif Adnan Zuhair \\ Politeknik Ilmu Permasyarakatan, email: afifadnanzuhair4@gmail.com
}

\begin{abstract}
Abstrak. Hak asasi merupakan suatu hak yang dipunyai oleh manusia. Undang-Undang No. 12 Tahun 1995 pasal 14 mengenai permasyarakatan yang mana juga meliputi berbagai hak narapidana yakni: mendapatkan hak pelayanan kesehatan, hak mendapatkan mendapatkan makanan yang layak, hak mendapatkan perawatan secara jasmani dan rohani. Narapinda merupakan terpidana dimana melaksanakan pidana yang kehilangan kemerdekaanya dalam Lembaga Pemasyarakatan. Pemberian pelayanan kesehatan pada Lembaga Permasyarakatan adalah sebuah perwujudan Hak Asasi Manusia. Berhasilnya pelayanan kesehatan tersebut juga adanya sebuah peran dari aktor kebijakannya atau stakeholder. Penelitian ini berfokus pada pelayanan kesehatan narapidana pada lembaga permasyarakatan di Indonesia dan juga optimalisasi stakeholder dalam pelayanan kesehatan di lembaga permasyaratan di Indonesia. Penelitian ini menggunakan tipe penelitian deskriptif dengan pendekatan kualitatif. Metode pengumpulan data dilakukan melalui dokumentasi dengan menghimpun berbagai sumber data sekunder yang memiliki keterkaitan dengan penelitian ini. Pelayanan kesehatan pada beberapa lembaga permasyarakatan di Indonesia, seperti Lembaga Permasyarakatan Narkotika Kabupaten Langsa Provinsi Aceh, Lembaga Permasyarakatan Perempuan Kelas IIA Yogyakarta, Lembaga Permasyarakatan Kelas II Manado masih belum baik dikarenakan banyak kendala pada dana, petugas kesehatan dan koordinasi dengan stakeholder lainnya. Diperlukannya stakeholder pada posisi penyelamat (saviour) dan kawan (friend) dapat diisi oleh dokter ataupun perawat kesehatan, Dinas Kesehatan pada posisi penyelamat (saviour), narapidana pada posisi pemerhati (acquintance).
\end{abstract}

Kata Kunci: Pelayanan Kesehatan, Narapidana, Stakeholder

\section{Optimization of Stakeholders in Inmate Health Services in Correctional Institutions}

\begin{abstract}
Abstrack. Human rights are rights that belong to humans. Law Number 12 of 1995 Article 14 concerning prison which also includes various prisoners' rights, namely: getting the right to health services, the right to get proper food, the right to receive physical and spiritual care. Prisoners are convicted who carry out crimes who lost their independence in the Penitentiary. Providing health services to Penitentiaries is an embodiment of Human Rights. The success of the health service is also the role of the policy actor or stakeholder. This research focuses on prisoner health services in prison in Indonesia and also the optimization of stakeholders in health services in prison in Indonesia. This research uses descriptive research type with a qualitative approach. The method of data collection is done through documentation by collecting various secondary data sources that are related to this research. Health services at several penitentiary institutions in Indonesia, such as the Narcotics Penitentiary in Langsa, Aceh Province, Yogyakarta Class IIA Women's Penitentiary, Manado Class II Penitentiary are still not good due to many constraints on funds, health workers and coordination with other stakeholders. The need for stakeholders in the position of savior (savior) and friend (friend) can be filled by doctors or health nurses, the Office of Health in the position of savior (savior), prisoners in the position of observers (acquintance).
\end{abstract}

Keywords: Health Services, Prisoners, Stakeholders

\section{Pendahuluan}

Hak asasi merupakan suatu hak yang dipunyai oleh manusia dimana sudah dibawanya juga didapatkannya pada saat hadirnya manusia tersebut ataupun kelahirannya di sebuah tatanan kehidupan masyarakat. Hak asasi manusia (human right) secara universal memiliki pengertian yaitu Those Rights 
Which Are Inherent In Our Nature And Whitout Which We Cannot Live As Human Being. Di dunia, hak asasi manusia dalam prosesnya sudah diakui juga dirumuskan melalui perjuangan panjang dengan rentang waktu yang juga tidak sebentar. Meskipun telah diakui, namun hak asasi manusia juga masih memunculkan bermacam-macam aspek masalah disebabkan bermacam-macam cara menafsirkan (Nazaryadi et al., 2017).

Negara Republik Indonesia membentu masyarakat yang adil dan maksud dimana didasarkan oleh pancasila. Terdapat penjelasan juga mengenai hal tersebut yakni pada Undang-Undang Dasar 1945 dalam Alenia ke-empat, dalam alenia ke-empat ini dijelaskan jika negara memiliki tujuan guna mewujudkan kesejahteraan kepentingan masyarakat. Dalam kalimat tersebut, bermakna jika kemerdekaan yang dimiliki masyarakat yang terambil haknya yang disebabkan adanya berbagai pelanggaran hukum juga mendapatkan jaminan, tidak hanya masyarakat yang tidak melakukan pelanggaran hukum atau masyarakat bebas hukum (Nazaryadi et al., 2017).

Narapinda merupakan terpidana dimana melaksanakan pidana yang mana terpidana tersebut kehilangan kemerdekaanya dalam Lembaga Pemasyarakatan. Pembinaan warga binaan permasyarakatan dilakukan pada LAPAS sedangkan pembinaan warga binaan permasyarakatan dilakukan pada BAPAS. Undang-Undang No. 12 Tahun 1995, menjelaskan jika petugas permasyarakatan sebagaimana dijelaskan pada UU tersebut pada pasal 7 ayat (1) adalah pekabat fungsional penegak hukum yangmana tugas yang dilaksanakan pada aspek pengamanan, pembinaan yang juga pembinaan warga binaan permasyarakat.
Sistem permasyarakat memiliki kegunaan untuk melakukan persiapan terhadap warga binaan permasyarakatan guna nantinya terdapat integrasi yang baik bersama masyarakat, agar warga binaan ini bisa menjalakannya perannya lagi menjadi anggota masyarakat yang bertanggungjawab dan bebas. UndangUndang No. 12 Tahun 1995 pasal 14 mengenai permasyarakatan yang mana juga meliputi berbagai hak narapidana yakni: mendapatkan hak pelayanan kesehatan, hak mendapatkan mendapatkan makanan yang layak, hak mendapatkan perawatan secara jasmani dan rohani. Hak Asasi Manusia (HAM) adalah hak yang telah melekat dalam manusia dimana menunjukan martabat manusia tersebut, wajib mendapatkan perlindungan hukum, karena hak tersebut bisa efektif hanya jika hak tersebut mendapatkan perlindungan hukum.

Lembaga permasyarakatan hingga saat ini sudah mengalami perubahan yang mencakup pembinaan narapidana dimana nantinya narapidana ini dapat bergabung lagi menjadi anggota pada lingkungan masyarakat. Narapidana ini juga sudah berubah namanya menjadi warga binaan permasyarakatan. Oleh karena itu, dikarenakan narapidana menjalani pembinaan, narapidan sebaiknya menjadi lebih baik dari keadaan sebelumnya, selain itu negara pun melakukan penjaminan narapidana. Jadi, diperlukan sebuah pembinaan juga perawatan narapindan dimana nantinya terdapat integrasi sosial. Adi Sujatno mengemukakan jika berubahnya sistem dalam penjara begerak pada sebuah sistem permasyarakatan, yangmana sistem ini merupakan sistem yang memiliki perlakuan pada narapidana secara normatif juga lebih manusiawi yang didasarkan oleh Pancasila. Terdapat konsep pendekatan pembinaan 
(treatment approach) dalam sistem permasyarakatan kini ditujukan agar bisa melaksanakan dalam upaya melindungi narapidana. Hak-hak narapidana saat melaksanakan hukuman, dijalankan dengan ciri-ciri integratif, edukatif, korektif juga rehabilitatif (Firmansyah et al., 2019).

Sehat adalah suatu kondisi yang mana tubuh manusia bebas penyakit, namun tidak hanya itu, sehat merupakan suatu kondisi yang mencakup semua dimensi kehidupan manusia dimana yang terdiri dari dimensi sipiritual, sosial, emosi juga fisik (Nazaryadi et al., 2017). World Health Organization (WHO) menjelaskan jika sehat memiliki pengertian yaitu sebuah sempurnanya kondisi yang meliputi kondisi mental, fisik, juga sosial sekaligus tak hanya bebas dari berbagai kelemahan ataupun penyakit. Menurut Undang-Undang Kesehatan No. 39 Tahun 2009, kesehatan merupakan kondisi yang sehat, meliputi sehat secara spiritual, fisik, dan juga mental dimana setiap orang dapat menjalani hidup dengan produktif baik dalam aspek ekonomi ataupun sosial.

Pemberian pelayanan kesehatan pada Lembaga Permasyarakatan adalah sebuah perwujudan Hak Asasi Manusia yang dapat diberikan oleh Negara untu warga negaranya. Dalam hal ini, pelaksanaan pelayanan kesehatan pada Lembaga Permasyarakatan dicantumkan pada beberapa peraturan perundangundangan yaitu:

a. Undang-Undang No. 39 Tahun 1999 mengenai Hak Asasi Manusia (HAM).

b. Undang-Undang No. 12 Tahun 1995 mengenai Pemasyarakatan.

c. Peraturan Pemerintan No. 58 Tahun 1999 mengenai tata cara juga persyaratan pelaksanaan tanggungjawab, wewenang juga tugas perawatan tahanan.

d. Permenkumham Nomor M.HH01.PK.07.02 Tahun 2009 mengenai Pedoman Penyelenggaraan Makanan Bagi Warga Binaan Pemasyarakatan pada Lembaga Permasyarakatan dan Rumah Tahanan Negara.

e. Permenkumham Nomor M.HH172.PL.02.03 Tahun 2011 mengenai Pedoman Pengadaan Bahan Makanan Bagi Narapidana, Tahanan, juga Anak Didik Permasyarakatan pada Lembaga Permasyarakatan dan Rumah Tahanan Negara di Lingkungan Kemenkumham.

Usaha dalam melindungi juga memajukan hak asasi untuk narapidana akan hak kesehatannya, tidak menjadi sebuah yang mudah juga bisa dilakukan pada waktu relatif singkat, namun berarti adalah sebuah keadaan yang relatif panjang dengan proses terus menerus, terpadu juga bekelanjutan dari segala pihak, yatiyu lembaga masyarakat dari bermacam-macam lapisan dan kalangan, berbagai organisasi sosial politik, juga pemerintah (Nazaryadi et al., 2017).

Berhasilnya suatu pembinaan pada lingkungan permasyarakatan juga merupakan adanya sebuah peran yang besar dari aktor kebijakannya. Aktor kebijakan merupakan pemangku kepentingan ataupun yang kerap mendapat sebutan stakeholder. Stakeholder merupakan sekumpulan orang dimana mempunyai suatu kepentingan akan sebuah program ataupun masalah, yang mana orangorang in mempunyai suatu power (kekuatan) guna memberikan pengaruh pada kebijakan serta berbagai pihak yang mempunyai kendali dan juga instrumen yang diperlukan untuk pelaksanaan program atau kebijakan tersebut. Analisis stakeholder sangat perlu 
dilakukan guna melakukan penilaian semua komponen keterlibatan stakeholder dalam penerapan program, secara khusus program dimana lebih dari satu instansi atau organisasi terlibat. Oleh karena itu, optimalisasi stakeholder pada proses pelaksanaan program ataupun kebijakan begitu penting guna memberikan penilaian sejauhmana stakeholder berperan guna mewujudkan berhasilnya program tersebut guna mengembangkan program secara terus menerus (Shinta Trinovia Kumalasari, Sutopo Patria Djati, 2018).

Sebelumnya, sudah terdapat peneliti yang melakukan penelitian terhadap pelayanan kesehatan pada lembaga permasyarakatan. Nazardi et al (2017) melakukan penelitian yang berjudul "Pemenuhan Hak kesehatan Narapidana Di Lembaga Permasyarakatan Nakotika Langsa". Hasil penelitian ini menunjukan bahwa pemenuhan hak kesehatan di lembaga permasyarakat Narkotika Kelas III Langsa belum terpenuhi sesuai dengan peraturan perundang-undangan yang berlaku, dikarenakan dalam pemberian pelayanan kesehatan belum berjalan secara baik dikarenakan belum memenuhi standar minimal pelayanan kesehatan bagi narapidana (Nazaryadi et al., 2017). Kemudian, terdapat penelitian dari Hakki Fajriando (2019) yang berjudul "Evaluasi Pelaksanaan Community Based Corrections Di Lapas Kelas III Rumbai". Hasil penelitian ini yaitu jika proses pembinaan di Lapas Kelas III Rumbai sudah berjalan, akan tetapi dalam pelaksanaan hak warga binaan belum berjalan dengan baik (Fajriando, 2019). Kedua penelitian diatas, merupakan penelitian dimana meneliti mengenai pelayanan kesehatan dan juga peran stakeholder dalam pelayanan kesehatan di lapas. Penelitian ini juga akan membahas mengenai pelayanan kesehatan dan juga optimaliasi stakeholder, apabila kedua penelitian terdahulu diatas berfokus pada satu lapas, penelitian ini akan mencoba melakukan kajian terhadap pelayanan kesehatan dari beberapa lapas di Indonesia.

Oleh karena itu, penelitian ini akan berfokus pada pelayanan kesehatan narapidana di lembaga permasyarakatan di Indonesia dan juga optimalisasi stakeholder dalam pelayanan kesehatan di lembaga permasyaratan di Indonesia yang nantinya, hasil pada penelitian ini dapat memberikan gambaran mengenai fokus masalah yang ingin dianalisis.

\section{Metode}

Penelitian ini menggunakan tipe penelitian deskriptif dengan pendekatan kualitatif. Tipe penelitian deskriptif memiliki peranan guna melaksanakan penyajian secara objektif tentang berbagai fenomena dimana yang ada pada suatu masalah penelitian. Pendekatan kualitatif memiliki sifat dalam melakukan penafsiran, penjelasan juga penggambaran hasil penelitian berdasarkan penyusunan kata-kata menjadi kalimat lengkap dimana menjadi jawaban dari masalah penelitian (Moleong, 2017). Sumber data penelitian yang akan digunakan oleh peneliti yaitu sumber data sekunder yang berasal dari literatur berupa jurnal dari penelitian terdahulu yang memiliki keterkaitan dengan masalah penelitian milik peneliti. Metode pengumpulan data dilakukan dengan dokumentasi, yangmana dokumentasi ini dilakukan guna menghimpun data dari berbagai sumber data sekunder dimana memiliki informasi tertentu yang memiliki keterkaitan dengan penelitian ini.

\section{Hasil Penelitian}


1. Pelayanan Kesehatan Narapidana di Lembaga Pemasyarakatan di Indonesia

a. Lembaga Permasyarakatan Narkotika, Kabupaten Langsa, Provinsi Aceh

a) Pemberian pelayanan kesehatan kurang maksimal, hal ini dikarenakan perawat merangkap tugasnya sebagai yang memberikan pelayanan kesehatan dan juga melakukan pengamanan sekaligus pemeriksaan kepada tamu yang melakukan kunjungan.

b) Makanan yang diberikan juga masih banyak mengandung minyak, belum memenuhi standar angka kecukupan gizi, selain itu fasilitas penyediaan dan penyimpanan makanan belum layak, dan juga jangka waktu pemasakan makanan dan penyajian makanan yang masih lama, hal ini bisa menyebabkan makanan menjadi rentan terhadap bakteri (Nazaryadi et al., 2017).

b. Lembaga Permasyarakatan Perempuan Kelas IIA Yogyakarta
a) Pada Lembaga

Permasyarakatan

Perempuan Kelas II Yogyakarta ini terdapat narapidana perempuan yang melahirkan, akan tetapi tidak berikan ruangan khusus untuk bayi, jadi bayi tetap tinggal bersama ibunya dan penghuni sel lainnya dalam sel yang sama. Hal ini memiliki resiko yang tinggi untuk bayi dikarena rentan terhadap penyakit dan juga psikologis bayi bisa terganggu.

b) Akan tetapi, dalam hal pemenuhan makanan dan pengecakan

kesehatan/pelayanan

kesehatan sudah berjalan baik.

c) Biaya tidak menjadi penghambat dalam pemberian pelayanan kesehatan, dikarenakan sudah dicover oleh BPJS (Kresnadari et al., 2013).

c. Lembaga Permasyarakatan Kelas II Manado

a) Petugas kesehatan dan penyediaan obat untuk narapidana masih sangat minim.

b) Biaya menjadi penghambat dalam ketersediaan obatobatan dan juga peralatan kesehatan.

c) Narapidana yang menderita penyakit kronis dan menular masih belum ditangani dengan baik, dikarenakan kurangnya koordinasi dengan Dinas Kesehatan ataupun rumah sakit (Kresnadari et al., 2013).

\section{Pembahasan}

\section{Pelayanan Kesehatan Narapidana di Lembaga Permasyarakatan di Indonesia}

Terdapat pelayanan kesehatan bagi narapidana pada beberapa lembaga permasyarakatan di beberapa daerah di Indonesia yang akan dianalisis dalam penelitian ini yakni sebagai berikut:
a. Lembaga
Permasyarakatan
Narkotika, Kabupaten Langsa, Provinsi Aceh


Petugas kesehatan wajib memberikan pelayanan kesehatan secara maksimal kepada seluruh narapidana maupun tahanan, dari mulai yang sakit maupun dalam keadaan sehat. Pemberian perawatan juga pemeriksaan kesehatan yang dilakukan oleh petugas kesehatan dinilai belum berlangsung dengan baik, ini dikarekan sebab terlalu terbatas juga sedikitnya sumber daya yang betugas pada Lembaga Permasyarakatan Narkotika Kelas III Langsa. Perawat di Lembaga Permasyarakatan Narkotika Kelas III Langsa, disamping memiliki tugas menjadi tenaga kesehatan dimana melakukan pelayanan kesehatan, selain itu memiliki tugas dalam mengamankan juga melakukan pemeriksaan pada tamu yang melakukan kunjungan atau membesuk narapidana. Keadaan tersebut menyebabakan, kondisi pelayanan kesehatan menjadi terganggu tidak bisa lagi dilakukan secara menyeluruh dan mendalam, hal yang lebih parah lagi yaitu dana kesehatan yang dialokasikan masih sedikit.

Undang-Undang Permasyarakatan No. 12 Tahun 1995 mengenai permasyarakatan memberi penjelasan jika pertugas wajib memberikan minuman juga makanan. Pemberiaan minuman dan makanan tersebut wajib memberi perhatian mengenai angka kecukupan gizi yang terdapat pada makanan, kesehatan juga kebersihannya. Narapidana pada Lembaga Permasyarakatan Narkotika Kelas III Langsa diberikan makanan yang mengandung seperti protein, karbohidrat juga nutrisi yang lainnya. Pada saat apapun dibutuhkan, warga binaan bisa memperoleh air minum yang sudah disediakan.

Pada saat menu makan bagi narapidana dibagikan, seperti yang sudah sering terjadi, menu makanannya mengandung banyak minyak seperti tahu dan tempe goreng, telur goreng, dimana nantinya dapat menyebabkan sebuah penyakit yakni radang tenggorokan ataupun batuk-batuk. Makanan mendapatkan kategori bisa untuk dikonsumsi jika telah terpenuhinya angka kecukupan gizi, bersih, juga terbebas dari bakteri yang mengkontaminasikan makanan tersebut sehingga makanan mengalami perubahan rasa, bau juga bentuknya.

Dalam hal memperoleh makanan yang layak sebagaimana merupakan salah satu hak narapidana yang harus dipenuhi pada Lembaga Permasyarakatan Narkotika Kelas III Langsa masih belum berlangsung secara baik dalam memenuhi asupan makanan berupa kalorinya untuk para narapidana, makanan belum tepenuhi standar angka kebutuhan gizinya, disebabkan masih terdapat banyak kelemahan juga kekurangan pada menu makanan yang diolah. Penyediaan makanan yang diberikan, masih dikatakan tidak tepenuhinya standar kelayakan makanan, dikarekan seperti belum memadainya dalam hal fasilitas penyimpanann makanan, tempat penyimpanan bahan makan juga belum terpenuhinya kriteria kelayakan penyimpanan, jangka waktu diantara proses pemasakan makanan dengan proses dibaginya makanan tersebut pada narapidana masih berjarak jauh, disebabkan hal tersebut makanan menjadi rusak kemudian tercemar oleh bakteri. bembaga Permasyarakatan
Perempuan Kelas IIB Yogyakarta

Dalam Lembaga permasyarakatan Perempuan Kelas IIB Yogyakarta terdapat narapidana perempuan yang melahirkan bayinya, akan tetapi dikarenakan tidak tersedianya ruangan secara khusus untuk bayi, maka bayi tersebut harus ikut tinggal bersama ibunya didalam satu sel yang sama 
dengan narapidana yang lain. Berdasarkan kondisi diatas, bayi yang tinggal dalam sel dan tidak berikan ruangan khusus dapat mempengaruhi akan kesehatan dikarenakan bayimasih sangat rentan terkena penyakit dan juga psikologis bayi juga akan tepengaruh. Belum adanya ruangan secara khusus yang dapat digunakan tahanan ataupun narapidana dalam keadaan hamil, sudah melahirkan juga sedang menyusui.

Pada pasal 20 ayat (1) Peraturan Pemeirntah No. 32 Tahun 1999 mengenai tata cara juga syarakat dalam pelaksanaan hak warga binaan dinyatakan jika narapidana yang juga memiliki anak didi permasyarakatan dimana sedang menyusui, sakit ataupun hamil memiliki hak untuk mendapat tambahan makanan yang disesuaikan oleh instruksi dokter. Pasal tersebut menjelaskan lebih lanjut bahwasanya makanan tambahan yang dimaksudkan dalam pasal tersebut merupakan ditambahkannya total kalori diatas ratarata total kalori yang sudah ditetapkan. Penambahan sebanyak 300 kalori diberikan kepada wanita hamil dalam sehari, diantara 800 hingga 1000 kalori ditambahkan untuk wanita menyusui dalam sehari. Didalam Lembaga Permasyarakatan, ibu dan juga bayinya diberikan tambahan makanan. Pemberian bubur kacang hijau juga susu diberikan untuk ibu hamil dan menyusui, selain itu dokter yang berada di Lembaga Permasyarakatan harus memberikan vitamin tambahan. Disebabakan tidak adanya bidan, maka pada narapidanan wanita yang melahirkan harus dibawa ke rumah sakit, karena terdapat resiko yang tinggi pada ibu melahirkan.

Warga binaan permasyarakatan memerlukan gizi yang seimbang pada makanan, dimana narapidan yang sedang hamil secara khusus memerlukan hal tersebut guna peningkatan juga pertahanan tingkat kesehatannya supaya bisa melakukan berbagai aktivitasnya juga bisa memastikan jika nantinya perkembangan juga pertumbuhan janin dengan sehat juga baik. Berdasarkan aturan 20 SMR dimana menjelaskan jika dalam memenuhi gizi untu seluruh warga binaan harus didasarkan oleh peraturan tersebut, jika setiap warga binaan permasyarakatan saat jam biasa wajib diberikan oleh pengelola lembaga permasyarakatan makanan dengan gizi yang cukup demi kekuatan juga kesehatan, selain itu penyajian, penyiapan harus juga dilakukan dengan sama baiknya.

Terdapat evaluasi juga dimana memiliki tujuannya yaitu guna melakukan penilaian dalam melaksanakan berbagai kegiatan untuk pelayanan kesehatan para narapidana wanita yang sedang hamil yang disesuaikan berdasarkan kebijakan juga rencana dimana sebelumnya sudah dilakukan penyusunan untuk narapidana wanita, pengelola, sekaligus petugas pelaksana di Lembaga Permasyarakatan Perempuan Kelas IIB Yogyakarta.

Dalam setiap pemberian makanan, selalu terdapat evaluasi sekaligus monitoring dari pihak Kasie Binadik, Dokter, Kepala Keamanan, juga Kepala Lapas Kelas IIA Yogyakarta untuk melakukan penunjangan kesehatan narapidana wanita termasuk didalamnya narapidana wanita hamil, oleh karenanya bisa mengecilkan berbagai masalah dan hambatan-hambatan yang ada. Monitoring juga evaluasi ini tak hanya dilaksanakan saat penyelenggaraannya saja, akan tetapi diterapkan pada setiap kegiatan pembinaan yang dilakukan pada Lembaga Permasyarakatan Kelas IIB Yogyakarta. Selain itu, pada hal memenuhi pelayanan kesehatan untuk narapidana wanita yang didalamnya terdapat narapidana wanita yang sedang hamil bisa diselenggarakan atau berjalan 
baik, hal ini dikarenakan terdapat kecekatan, ketanggapan, juga kesiagaan petugas permasyarakatan. Perlunya biaya yang banyak sudah menjadi hal yang biasa untuk sebuah pelayanan kesehatan yang baik. Salah satu hal yang dapat menghambat dalam menjalankan sebagai usaha dalam memenuhi pelayanan kesehataan adalah biaya, biaya kini tidak lagi menjadi sebuah hambatan ataupun masalah untuk Lembaga Permasyarakatan Perempuan Kelas IIB Yogyakarta dikarenakan seluruh biaya sudah ditanggung oleh pemerintah lewat BPJS.

c. Lembaga Permasyarakatan Kelas IIA Manado

Dalam hak untuk didapatkannya pengobatan pada Lembaga Permasyarakatan Kelas IIA Manado yangmana dalam pelaksanaannya masih terdapat hambatan. Akibatnya, dikarenaka masih minimnya ketersediaan dan pengadaan obat-obatan dan juga tenapa petugas kesehatan, akan tetapi penentuan anggaran yang dilakukan oleh DIPA Lembaga Permasyarakatan dalam hal dalam memenuhi hak narapidan guna didapatkan obat-obat bagi narapidan masih berjalan, walaupun disesuaikan dengan keadaan anggaran.

Pasokan obat-obatan, peralatan, juga perabotan wajih terus dipenuhi guna melaksanakan perawatan media apabila terdapat fasilitas rumah sakit didalam sebuah lembaga permasyarakatan guna melakukan perawatan pada narapidana yang sakit, juga wajib diberikan petugas kesehatan dimana memiliki kemampuan yang sesuai. Seluruh narapidan juga wajib diberikan layanan kesehatan gigi. Petugas kesehatan wajib melakukan kunjungan pada seluruh narapidana yang satiap setiap harinya, selain itu juga wajib melakukan perawatan kesehatan jasmani narapidana, ataupun juga jika terdapat keluhan sakit dari narapindana.

Pada saat waktu pertama narapidana memasuki lembaga permasyarakata, pemeriksaaan kesehatan telak dilaksanakan. Diberikannya kartu berobat pada seluruh narapidana yang bisa digunakan untuk catatan kontrol kesehatan. Pukul 09.00 Wita hingga 12.00 Wita merupakan jadwal prakterk dokter pada Lembaga Permasyarakatan Kelas IIA Manado.

Akan tetapi, ketersediaan obat-obatan yang adanya yang diakibatkan dari kurangnya alokasi dana yang memadai, berdampak pada obat-obatan yang ketersediaannya tidak memadai, dan juga obat-obatan yang diberikan pada narapidana yang berobat tidak dilakuka secara maksimal sesuai berdasarkan spesifikasi atau indikasi penyakita yang diberikan, yang kemudian terjadi adalah tidak bisa terjadi kesembuhan yang maksimal dari narapidana. Selain itu, masih kurangnya jumlah tenaga media atau paramedia petugas kesehatan, mengakibatkan waktu pelayanan narapidana yang sakit sangat sedikit atau teradapat keterbatasan waktu pelayanan kesehatan.

Narapidana yang mengidap penyakit kronis maupun penyakit khusus semacam TBC, HIV/AIDS serta penyakit menular lainnya wajib untuk memperoleh pelayanan yang lebih ekstra lagi dan pegawai kesehatan Lapas juga melayaninya. Adanya servis kesehatan secara serius dengan interes khusus amat diperlukan oleh mereka. Atas aturan resmi mengenai seorang narapidana yang terserang penyakit khusus membutuhkan perawatan oleh dokter spesialis dan juga bakal dilakukannya pemindahan ke lembaga khusus ataupun rumah sakit umum. Hak dalam memperoleh sarana dan prasarana terhadap pelayanan 
khusus meliputi adanya tempat tersendiri untuk naparapidana tersebut, diberikan rujukan untuk bisa berobat ke rumah sakit dengan penyakit yang dialaminya, Narapidana yang memiliki penyakit tersebut tidak bercampur dengan narapidana lainnya serta memperoleh tindakan perawatan yang berkelanjutan atau berkesinambungan.

Bersangkutan dengan adanya pelaksanaan hak dalam mendapatkan sarana dan prasarana terhadap pelayanan khusus untuk narapidana yang memiliki penyakit HIV/AIDS, TBC maupun penyakit menular lainnya diprediksikan belum optimal lantaran kurangnya koordinasi dengan lembaga yang terkait meliputi Dinas Kesehatan, Rumah Sakit dan koordinasi pada Dokter Ahli. Selain itu pegawai kesehatan Lapas Klas IIA Manado masih sedikit serta dana operasioanal mengenai persediaan obat-obatan yang kurang. Persoalan ini dikarenakan minimnya koordinasi dan komunikasi terhadap instansi yang terkait serta sedikitnya dokter ahli yang ada untuk menangani penyakit khusus ataupun penyakit menular dan didukung lagi dengan sarana poliklinik, obatobatan yang tersedia, serta tenaga petugas kesehatan Lapas Klas IIA Manado yang sedikit.

\section{Optimalisasi Stakeholder dalam Pelayanan Kesehatan pada Lembaga Permasyarakatan di Indonesia}

1. Identifikasi Stakeholders

Identifikasi stakeholders penelitian ini ialah suatu proses dalam mengidentifikasi seseorang, organisasi atau lembaga yang berperan dalam mempengaruhi serta dipengaruhi pada pelaksanaan pelayanan kesehatan. Identifikasi tersebut didasarkan pada tiga klasifikasi Greene yakni stakeholders penyelenggara, stakeholders target, serta stakeholders pengelola keputusan (Kumalasari et al, 2018, h.172)

Perolehan hasil dari identifikasi stakeholders didapatkan klasifikasi meliputi Dinas Kesehatan yang terlibat pada stakeholders pengelola keputusan. Dokter, Tenaga Pencatatan dan Pelaporan, serta Kader termasuk stakeholders penyelenggara dan Narapidana disebut dengan stakeholders target.

\section{Peran Stakeholder}

Klasifikasi stakeholder yang telah diterima akan menjalani proses konfirmasi yang bertujuan untuk melihat keselarasan terhadap peran yang dikerjakan. Peran berarti dengan sebuah usaha yang dilakukan menurut fungsi serta posisinya di dalam jabatan tersebut. Konfirmasi peran stakeholder ditinjau dari kepentingan dan kewenangan.

\section{Kepentingan}

Kepentingan dimaksud dengan faktorfaktor yang melatarbelakangi stakeholders untuk mengutamakan suatu rencana. seorang peneliti melakukan interpretasi dalam kepentingan dengan aspek pengetahuan, pendapat antar stakeholder, harapan dan kendala.

Aspek pengetahuan stakeholders untuk memahami sebuah program, fungsi dan kekuasaannya banyak dipengaruhi oleh diseminasi informasi yang didapatkan, intensitas training yang diterima serta transparansi mengenai tugas yang diuraikan dalam bentuk tertulis. Hal penting ini diperlukan oleh stakeholders termasuk Narapidana yang masuk dalam klasifikasi stakeholders target dan stakeholders penyelenggara.

Aspek harapan stakeholders memperlihatkan perkiraan positif dalam program, mengharapkan kelangsungan dari semua stakeholder pada pelayanan 
kesehatan supaya warga binaan permasyarakatan bisa tetap dalam kondisi yang sehat.

Aspek ketiga yaitu hambatan yang dialami oleh stakeholders program. Hambatan tersebut tidak sama antar stakeholders. Komunitas stakeholders pengelola keputusan menghadapi hambatan pokoknya ialah pada dependensi guna memberikan kesediaan tempat isolasi secara khusus dan juga dipisahkan dengan blok hunian, diseminasi informasi diantara stakeholder juga terbatasnya suatu anggaran guna pemeberian pelatihan pada kader. Adanya kendala lainya yang terjadi pada stakeholders pelaksana juga target yang utama yakni standar dan mekanisme yang belum ada guna ditetapkannya menjadi kader, narapidana tersebut masih banyak melakukan penolakan padahal kader tersebut berfungsi sebagai pengingat mengenai kesehatan mereka, dikarenakan juga rendahnya tingkat kesadaran akan kesehatan pribadinya.

Aspek terakhir adalah pendapat antar stakeholders. Seluruh stakeholders memberikan pendappat yang positif kepada antar stakeholders. Hal ini adalah poin penting guna memastikan seluruh stakeholders mendukung program. Aspek yang terakhir yakni pendapat diantara stakeholder. Semua stakeholder bisa menyampaikan pendapat yang positif dengan sesama stakeholder. Hal tersebut merupakan suatu kunci untuk melakukan pemastian bahwa semua stakeholder memberikan dukungan pada program.

\section{Kewenangan}

Seluruh stakeholder mempunyai berbagai perbedaan kewenangan yang disesuaikan berdasarkan kualifikasi sebelumnya, kewenangan ini dibagai atas stakeholder taget, stakeholder pengambila keputusan juga stakeholder pelaksanan. Masingmasing stakeholder ini menjalankan perannya yang sudah disesuaikan berdasarkan pengertian dari kewenangan masing-masing yaitu sebagai yang membuat suatu keputusan, yangmana stakeholder ini memiliki wewenang guna memberikan persetujuan juga pertimbangan akan keputusan/program yang akan diputuskan, lalu pada akhirnya setelah program diputuskan, program ini akan dijalankan. Kemudian, stakeholder pelaksana memiliki peran guna melaksanakan kewenangannya sebagai pelaksana teknis dilapangan, yaitu menjalankan tanggungjawabnya untuk keberlanjutan dari aspek administrasinya ataupun programnya, lalu stakeholder target yang nantinya akan mendapatkan kegunaan dari jalannya program tersebut. Oleh karena itu, disini sudah jelas masing-masing kewenangan yang dimiliki stakeholder, yang nantinya sudah ada kewenang yang jelas tidak akan terjadi tumpang tindih kewenangan.

\section{Posisi Stakeholders}

Sebuah program yang berhasil sangat tergantung pada peran masing-masing stakeholder, artinya stakeholder sangat mempengaruhi keberhasilan program. Manajemen dalam pelayanan kesehatan bisa memberikan rekomendasi berdasarkan posisi yang dipertimbangkan, yang nantinya program ini dapat berjalan dengan baik.

Penilaian akan posisi stakeholder berdasarkan 3 aspek yakni aspek keterlibatan (interest), sikap (attitude), pengaruh ataupun tingkatan kekuatannya (influence). Sikap merupakan respon tertutup dari stakeholder akan program dimana memiliki keterkaitan dengan pelayanan kesehatan yang dijalankan. Aspek sikap ini dibagi menjadi 2 yakni sikap yang memberikan dukungan juga sikap yang tidak memberikan dukungan. Aspke 
sikap juga dinalai berdasarkan sikap masing-masing stakeholder yaitu dalam hal memberikan obat, menangani kasus suatu penyakit, menemukan suatu penyakit, mengendalikan faktor resikonya, dan juga seperti kegiatan guna mempromosikan kesehatan pada lembaga permasyarakatan. Aspek kedua yakni keterlibatan (interest) merupakan sebuah usaha dalam partisipasi masing-masing stakeholder guna memberikan perannya dalam pelaksanan pelayanana kesehatan. Penialain keterlibatan ini yaitu aktif atau pasif. Aspek yang ketiga yaitu pengaruh. Dalam hal ini pengaruh adalah sebuah kekuatan yang dimiliki guna melakukan kontrol pada keputusan yang diambil, memberikan fasilitas untuk pelaksanaan, juga memiliki kemampuan untuk mendorong yang lainya agar melakukan juga menghindari segala hal yang nantinya berpengaruh pada pelaksanaan pelayanan. Stakeholder yang mempunyai pengaruh kuat, dimana bisa pengaruh tersebut diberikan lewat pengawasan juga advokasi yaitu Dinas Kesehatan, lalu stakeholder yang mempunyai pengaruh lemah yaitu Dokter, Kader, Petugas Monev, juga Narapidana.

\section{Pemetaan Posisi}

Berdasarkan kirteria, dapat dilakukan penetuan posisi stakeholder sebagai berikut:

a. Penyelamat (Saviour) merupakan stakeholder dimana memiliki keterlibatan aktif, sikap mendukung juga berpengaruh tinggi. Perlunya terus penjagaan untuk stakeholder pada posisi ini untuk tetapi memberika dukuang pada pelayanan kesehatan secara terus-menerus.

b. Perusuh (Terorist) merupakan stakeholder dimana memiliki keterlibatan yang aktif dalam program, akan tetapi sikapnya tidak memberikan dukungan, namun berpengaruh tinggi. Stakeholder semacam ini, harus agar dikeluarkan dalam formasi stakeholder.

c. Kawan (Friend) merupakan stakeholder dimana mempunyai keterlibatan yang aktif, tetapi memiliki rendahnya pengaruh, namun sikapnya positif.

d. Pengganggu (Irritant) merupakan stakeholder dimana mempunyai keterlibatan yang aktif, namun sikap yan tidak mendukung dan juga pengaruhnya rendah.

e. Raksasa tidur (sleepingb beauty) merupakan stakeholder dimana memilik pengaruh yang tinggi, sikapnya mendukung akan tetapi keterlibatannya rendah. Stakeholder sejenis ini diperlukan adanya dorongan guna peningkatan keterlibatan.

f. Pemerhati (acquintance) merupakan stakeholder dimana mempunyai suatu rendahnya kepentingan, pengaruhnya rendah, sikapnya menunjukan dukungan akan tetapi tak memiliki banyak keterlibatan. Perluanya sebuah komunikasi agar hubungannya tetap terjaga.

g. Bom wkatu merupakan stakeholder dimana mempunyai tingkat pengaruh yang tinggi, akan tetapi mempunyai sikap tak memberikan dukungan, juga keterlibatannya tiadak aktif. Stakeholder sejenis ini diperlukan untuk diberikan perhatian juga ajakan berdiskusi guna sebagai pengingat pada kelebihan yang dimiliki masingmasing.

Berdasarkan, uraian yang difokuskan pada aspek keterlibatan, sikap, juga pengaruhnya, oleh karena itu penentuan posisi stakeholder dalam pelayanan kesehatan di Lembaga Permasyarakatan yakni: 
a. Posisi penyelemat (Saviour) dan juga kawan (Friend) dapat diisi oleh Dokter ataupun perawat kesehatan. Pada posisi ini, perlunya sebuah perhatian secara terus menerus pada stakeholder agar terus memberikan dukungan juga secara penuh melaksanakan peran dalam pelayanan kesehatan ini. Selain itu, pimpinan lembaga permasyarakatan atau Kepala Lapas perlu memperhatikan stakeholder untuk melakukan pengembangan dan perbaikan pelayanan untuk kedepan. Selain itu, sebagai pihak yang dijadikan sebagai kawan (friend) stakeholder menjadi seseorang yang menjadi pihak yang diberikan kepercayaan didalam pelayanan kesehatan ini. Stakeholder yang membuat keputusan bisa melakukan permintaan saran ataupun pendapatan agar memperbaiki juga memberikan bantuan agar pelayanan kesehatan menjadi berhasil.

b. Posisi penyelamat (saviour) juga dapat diisi oleh Dinas Kesehatan setempat, dimana dalam hal ini Dinas Kesehatan bisa membuat dan mengembangkan program-program yang berpihak pada narapidana untuk dipenuhi hak asasinya dalam mendapatkan pelayanan kesehatan yang layak, memberikan dukungan penuh, juga melakukan monitoring terhadap hal-hal yang masih menjadi hambatan dalam pemberiaan layanan kesehatan.

c. Narapidana pada lembaga permasyarakatan menduduki pada posisi pemerhati (acquintance). Kecenderungan yang dimiliki oleh narapidana adalah keterlibatan yang pasif dan juga masih rendah. Diperlukan pemberian informasi secara berkelanjutan juga pelayanan yang terbaik untuk Narapidana ini, supaya mereka tetap dalam kondisi yang selalu sehat mendapatkan hak asasinya dan juga merasa puas akan pelayanan kesehatan yang diberikan.

\section{Kesimpulan}

Pelayanan kesehatan pada beberapa lembaga permasyarakatan di Indonesia, seperti Lembaga Permasyarakatan Narkotika Kabupaten Langsa Provinsi Aceh masih belum baik masih terdapat banyak kendala seperti petugas kesehatan yang kurang maksimal dan pemberian makanan untuk narapidana belum memenuhi standar kelayakan gizi, pada Lembaga Permasyarakatan Perempuan Kelas IIA Yogyakarta dalam pemberian pelayanan sudah baik, akan tetapi bayi narapidana perempuan yang memiliki bayi belum diberikan haknya sepenuhnya, dikarenakan bayi tidak diberikan ruangan tinggal secara khusus, pada Lembaga Permasyarakatan Kelas II Manado masih belum baik dikarenakan petugas keseharan, dana dan juga kurangnya koordinasi dengan stakeholder lain masih menjadi hambatan. Diperlukannya stakeholder pada posisi penyelamat (saviour) dan kawan (friend) dapat diisi oleh dokter ataupun perawat kesehatan yang mana bisa memberikan perhatian dan kepercayaan untuk memberikan pelayanan yang terbaik, Dinas Kesehatan pada posisi penyelamat (saviour) bisa terus mengembangkan program yang berpihak pada pemenuhan pelayanan kesehatan bagi narapidana, narapidana pada posisi pemerhati (acquintance) perlu diberikan informasi secara terus menerus dan pelayanan yang terbaik agar bisa mendapatkan hak asasinya dalam mendapatkan kesehatan secara baik dengan penuh.

\section{Daftar Pustaka}

Fajriando, H. (2019). Evaluasi 
Pelaksanaan Community-Based Corrections di Lapas Terbuka Kelas III Rumbai. Jurnal Ilmiah Kebijakan Hukum, 13(3), 323-338. https://doi.org/10.30641/kebijakan.2 019.v13.323-338

Firmansyah, R., A.Rani, F., \& Adwani, A. (2019). Pemenuhan Pelayanan Kesehatan dan Konsumsi Bagi Narapidana di Lapas dan Rutan. Jurnal Magister Hukum Udayana (Udayana Master Law Journal), $8(3)$, $433-448$. https://doi.org/10.24843/jmhu.2019. v08.i03.p10

Kresnadari, A., Isharyanto, \& Supanto. (2013). PELAKSANAAN PEMENUHAN HAK ATAS PELAYANAN KESEHATAN BAGI PEREMPUAN NARAPIDANA DALAM
Lembaga Pemasyarakatan Perempuan Kelas IIB Yogyakarta). Jurnal Hukum Dan Pembangunan Ekonomi, 6(2), 240-259.

Moleong. (2017). Metode Penelitian Kualitatif. PT Remaja Rosdakarya.

Nazaryadi, Adwani, \& Ali, D. (2017). Pemenuhan Hak Kesehatan Narapidana di Lembaga Pemasyarakatan Narkotika Langsa, Aceh. 1(1), 157-168.

Shinta Trinovia Kumalasari, Sutopo Patria Djati, N. A. Y. D. (2018). ANALISIS POSISI STAKEHOLDERS PROGRAM PENANGGULANGAN TB DI LAPAS KLAS I SEMARANG. JURNAL KESEHATAN MASYARAKAT (e-Journal), 6(5), 170-179. 